\title{
Strategi City Branding Terhadap Minat Kunjung Wisatawan
}

\author{
Anwar \\ Universitas Amir Hamzah \\ anwar.nuar1963@gmail.com
}

\begin{abstract}
Abstrak
Tujuan dari Penelitian ini adalah untuk menganalis Strategi City Branding (Presence, Potential, Place, People, Pulse, dan Prerequisite) terhadap minat kunjung wisatawan Istana Maimun studi kasus Istana Maimun Medan. Penelitian ini menggunakan rumus slovin dengan 73 responden yang merupakan wisatawan Istana Maimun yang berkunjung ke Istama Maimun kota Medan. Penelitian ini menggunakan metode linier berganda untuk mengetahui pengaruh variabel intervening. Hasil penemuan dari penelitian ini menujukkan bahwa variabel city branding berpengaruh secara parsial terhadap minat kunjung wisatawan Istana Maimum, dan secara simultan potential, place, dan pulse berpengaruh signifikan, yang tidak signifikan adalah presence, people dan prerequisite terhadap minat kunjung wisatawan Istana Maimun.
\end{abstract}

Keyword: City Branding; Minat Kunjung.

\section{PENDAHULUAN}

Parawisata di Indonesia merupakan sektor ekonomi penting di Indonesia yang menempati urutan ketiga dalam hal penerimaan devisa setelah komoditi minyak dan gas bumi serta minyak kelapa sawit. Selama tahun 2019, jumlah kunjungan wisman ke Indonesia mencapai 15,81 juta kunjungan atau naik 12,58\% dibandingkan dengan jumlah kunjungan wisman pada periode yang sama tahun 2018 yang berjumlah 14,04 juta kunjungan.

Sumatera Utara yang merupakan salah satu provinsi di Indonesia mempunyai danau yang masuk dalam 10 destinasi unggulan di Indonesia. Danau Toba juga salah satu destinasi yang diterima UNESCO sebagai salah satu Global Geopark, sebuah objek wisata alam yang harus dilindungi. Ini akan berdampak sangat besar bagi parawisata, karena wisatawan akan dimanjakan indahnya pemandangan danau yang dikelilingin pegunungan hijau. Destinasi di Sumatera Utara juga sangat beragam 
Tabel 1. Jumlah Kedatangan Wisatawan Mancanegara Ke Indonesia Menurut Pintu Masuk Bandara Tahun 2018 - 2020

\begin{tabular}{|l|c|c|c|r|r|r|r|r|r|}
\hline Tahun & \multicolumn{10}{|c|}{ Bandara } \\
\cline { 2 - 10 } & $\begin{array}{c}\text { Ngurah } \\
\text { Rai }\end{array}$ & \% & $\begin{array}{c}\text { Soekarno } \\
\text { Hatta }\end{array}$ & \% & Batam & \% & Kualanamu & \% & $\begin{array}{r}\text { perkembangan } \\
\text { \% }\end{array}$ \\
\hline 2018 & 3.731 .735 & 39.55 & 2.246 .437 & 23.8 & 1.454 .110 & 15.41 & 234.724 & 2.48 & 4.06 \\
\hline 2019 & 2.951 .565 & 38.29 & 1.816 .994 & 23.57 & 1.197 .164 & 15.53 & 154.741 & 2.01 & -34.07 \\
\hline 2020 & 3.620 .761 & 43.29 & 1.913 .847 & 22.88 & 1.113 .030 & 15.3 & 141.426 & 1.69 & -8.6 \\
\hline
\end{tabular}

Dari data jumlah pada tabel 1 kedatangan wisatawan melalui pintu masuk kualanamu mengalami penurunan dari tahun 2018 - 2020 hanya berjumlah $1.69 \%$ yang ada di peringkat ke 4 dari bandara Ngurah Rai sebesar 43,29\% lalu bandara Soekarno Hatta sebesar 22,88\% dan di susul Bandara Batam sebesar 15.3\%. Sektor parawisata sebagai kegiatan yang strategis dari pengembangan ekonomi dan sosial budaya keparawisataan dapat mendorong terciptanya lapangan pekerjaan, peningkatan pendapatan masyarakat, peningkatan kualitas masyarakat juga dapat menambah cinta tanah air serta nilai - nilai budaya, bangsa, dan pelestarian alam ( Pitana : 2010).

Kota Medan memiliki sebuah istana megah yang menjadi istana peninggalan budaya melayu yang diberi nama Istana Maimun dan menjadi salah satu istana terindah di Indonesia. Istana maimun terkadang disebut juga Istana Putri Hijau , yang merupakan istana kebesaran Kerajaan Deli. Pembangunan istana selesai pada 25 agustus 1888 M, dimasa kekuasaan Sultan Makmun al - Rasyid Perkasa Alamsyah dan engan adanya tempat bersejarah nan megah ini, Medan menjadikan Istana Maimun sebagai ikon parawisata kota Medan Slogan dari Sumatera Utara adalah "Horas Medan Menjuah Juah" sedangankan slogan dari Medan sendiri adalah "Assalamualaikum Ahoi “ sayangnya slogan ini jarang kita dengan. Kita lebih sering mendengar slogan " Horas Medan".

\section{Tinjauan Pustaka}

\section{Pariwisata}

Menurut etimologi kata "pariwisata" diidentikkan dengan kata "travel" dalam bahasa Inggris yang diartikan sebagai perjalanan yang dilakukan berkali-kali dari satu tempat ke tempat lain. Atas dasar itu pula dengan melihat situasi dan kondisi saat ini pariwisata dapat diartikan sebagai suatu perjalanan terencana yang dilakukan secara individu atau kelompok dari satu tempat ke tempat lain dengan tujuan untuk mendapatkan kepuasan dan kesenangan (Sinaga, 2010). 
Komisi liga bangsa - bangsa menyempurnakan pengertian wisatawan dengan mengelompokkan orang - orang yang dapat disebut wisatawan dan bukan wisatawan. Komisi merumuskan yang merupakan wisatawan adalah, (a) mereka yang mengadakan perjalanan untuk kesenangan karna alasan keluarga, kesehatan, dan lain - lain, (b) mereka yang mengadakan perjalanan untuk keperluan pertemuan - pertemuan atau tugas tertentu (tugas Negara, pengetahuan, agama, olahraga, (c) mereka yang mengadakan perjalanan dengan tujuan usaha, (d) mereka yang datang dalam rangka perjalanan dengan kapal laut maupun berada disuatu Negara kurang dari 24 jam.

Yang tidak dapat dikatan wisatawan adalah, (a) mereka yang datang memangku jabatan atau mengadakan usaha disuatu Negara, (b) mereka yang datang untuk menetap, (d) penduduk derah perbatasan dan orang yang tinggal di Negara yang satu, akan tetapi bekerja di Negara tetangga, (c) pelajar, mahasiswa dan kaum muda di tempat - tempat pemondokan dan di sekolah - sekolah, (d) orang yang dalam perjalanan melalui sebuah Negara tanpa berhenti disitu,meskipun di Negara itu lebih dari 24 jam.

\section{City Branding}

Menurut Simon Anholt dalam Moilanen dan Rainisto (2010) mengidentifikasikan sebagai manajemen suatu citra destinasi melalui inovasi strategis serta koordinasi ekonomi, komersial, sosial, cultural dan peraturan pemerintah. Menurut Dinnie (2011) City Branding adalah mengidentifikasi suatu set brand attributes sebagai yang dimiliki sebagai sebuah kota sesuai urutan untuk membentuk sebuah dasar yang digunakan untuk menghasilkan persepsi positif dan banyak audiences.

City Branding memiliki fungsi sebagai alat untuk mengkomunikasikan tempat (kota, kabupaten atau provinsi) pada pemangku kepentingan (Yananda dan Salamah, 2014). Menurut Prasetyo (2012) City Branding adalah proses atau usaha membentuk brand dari suatu kota untuk mempermudah pemilik kota tersebut memperkenalkan kotanya kepada target pasar (investor, tourist, talent,event) kota tersebut dengan menggunakan kalimat positioning, slogan, icon, eksibisi dan berbagai media lainnya.

Terdapat beberapa kriteria dalam membuat City Branding yang harus dipenuhi menurut Yuli (2011) diantaranya; Attributes, city branding mampu menggambarkan sebuah karakter, daya tarik, gaya dan personalitas kota.; Message, menggambarkan sebuah cerita secara pintar, menyenangkan dan mudah atau selalu diingat.; Differentiation, memberikan kesan unik dan berbeda dari kota - kota yang lain;; Ambassadorship, menginspirasi orang untuk datang dan ingin tinggal dikota tersebut.

Beberapa kota melakukan strategi dengan menerapkan City Branding, hal ini dianggap menguntungkan bagi para pemangku kepentingan. Berikut alasan mengapa city branding perlu dilakukan menurut Handito, (dalam Sugiarsono, 2010): 
Memperkenalkan kota atau daerah lebih dalam penerapan City Branding; Memperbaiki citra suatu kota yang sudah dinilai buruk oleh pengunjung maupun penduduk kota sendiri; Menarik wisatawan asing dan domestic

Menurut Porpescu dan Cabos (dalam wibisono 2015) memaparkan City Branding Hexagon memberikan instrument pengukuran inovatif sehingga dapat mempermudah pemerintah untuk mengetahui persepsi mengenai citra kota. City branding hexagon diciptakan oleh Simon Anholt (2010) untuk mengukur efektivitas City Branding. Terdapat enam aspek dalam pengukuran efektivitas City Branding yang terdiri atas presence, potential, place, pilse, people, dan prerequisite.

\section{Minat Berkunjung}

Teori minat berkunjung dianalogikan sama dengan minat beli, seperti penelitian yang dilakukan oleh Albarq (2014) yang menyampaikan bahwa minat berkunjung wisatawan sama dengan minat pembelian konsumen. Selain itu Kotler et al (2010) dalam Ramadhan dkk (2015) mengasumsi bahwa minat pembelianpada konsumen dapat disamakan dengan minat berkunjung pada wisatawan.

\section{RESEARCH QUESTIONS}

Adapun kerangka konseptual dalam penelitian ini untuk melihat keterkaitan antar variabel bebas terhadap variabel terikat yaitu City Branding. Variabel terikatnya merupakan minat kunjung wisatawan.

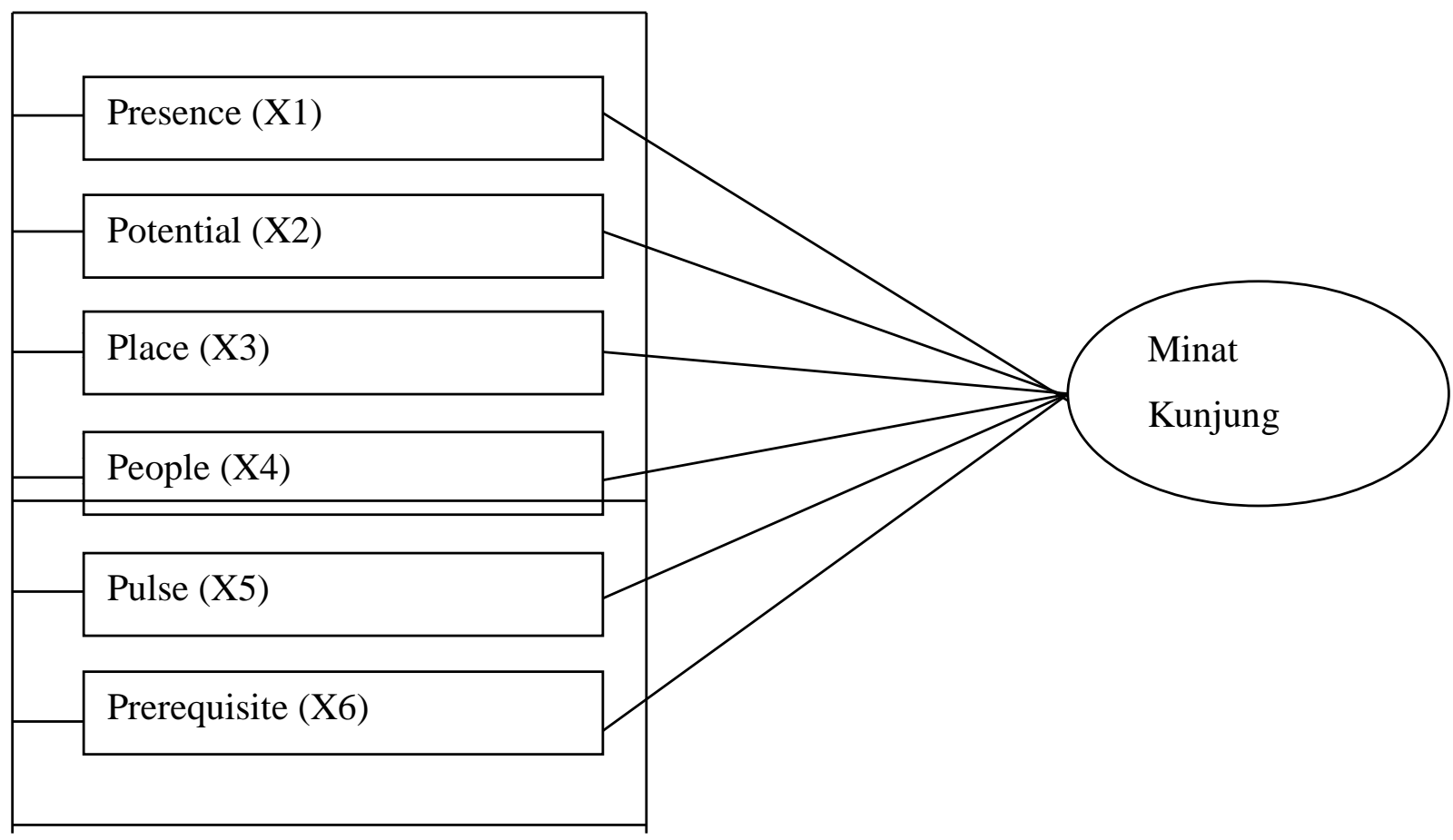

Jurnal Insitusi Politeknik Ganesha Medan

Juripol, Volume 4 Nomor 2 September 2021 
Sumber : Diolah oleh penulis (2021)

\section{Gambar 1. Kerangka Konseptual}

Dengan Hipotesis (1) Ada pengaruh positif dan signifikan secara terpisah presence terhadap minat kunjung wisatawan Istana Maimun. (2) Ada pengaruh positif dan signifikan secara terpisah potential terhadap minat kunjung wisatawan Istana Maimun. (3)Ada pengaruh positif dan signifikan secara terpisah place terhadap minat kunjung wisatawan Istana Maimun. (4)Ada pengaruh positif dan signifikan secara terpisah people terhadap minat kunjung wisatawan Istana Maimun. (5) Ada pengaruh positif dan signifikan secara terpisah pulse terhadap minat kunjung wisatawan Istana Maimun. (6) Ada pengaruh positif dan signifikan secara terpisah prerequisite terhadap minat kunjung wisatawan Istana Maimun. (7) Ada pengaruh positif dan signifikan secara terpisah presence, potential, place, people, pulse, prerequisite terhadap minat kunjung wisatawan Istana Maimun.

\section{METHOD}

Penelitian inin menggunakan penelitian asosiatif yang bertujuan untuk mengetahui derajat hubungan dan bentuk pengerauh antar dua variabel atau lebih Sugiono (2010), dimana penelitian ini membahas City Branding terhadap minat kunjung wisatawan.

Penelitian ini dilaksanakan di Istana Maimun Medan jalan dan dimulai pada bulan Januari 2021. Adapun yang menjadi populasi dalam penelitian ini merupakan tempat wisata Istana Maimun Kota Medan. Penentuan sampel dalam penelitian ini menggunakan rumus pengambilan sempel menurut Sugiono (2009) apabila populasi tidak diketahui secara pasti adalah sebagai berikut :

$$
\mathrm{n}=\frac{\mathrm{N}}{1+\mathrm{N}(\mathrm{e})^{2}}
$$

Dimana berdasarkan pendapat tersebut diatas maka didalam penelitian ini penulis mengambil sampel 73 responden.

Jenis data pada penelitian ini adalah data primer yang merupakan data mentah yang diambil oleh peneliti sendiri dari sumber utama guna kepentingan penelitiannya, dan data tersebut sebelumnya tidak ada dan data Sekunder merupakan data yang sudah tersedia yang dikutip oleh peneliti guna kepentingan penelitiannya dsalam data aslinya 
tidak diambil peneliti atau pihak lain. Dalam penelitian ini data diperoleh melalui buku teori, karya ilmiah, jurnal yang berhubungan dengan masalah yang diteliti.

Sumber data yang digunakan dalam penelitian ini meliputi: (a) Angketangket/kuesioner, (b) Observasi, dan (c) Wawancara.

Penelitian ini menggunakan 1 (satu) variabel bebas (independent) yaitu (X1) city branding, serta variabel terikat (dependent) yaitu : minat kunjung wisatawan (Y1).

Tabel 2. Variabel Penelitian Dan Definisi Operasional

\begin{tabular}{|c|c|c|c|}
\hline Variabel & Deskripsi & Indikator & Skala \\
\hline $\begin{array}{l}\text { Presence } \\
\text { X1 }\end{array}$ & $\begin{array}{l}\text { Keakraban } \\
\text { adalah } \\
\text { hubungan yang } \\
\text { berkembang } \\
\text { antar individu } \\
\text { sebagai hasil } \\
\text { interaksi } \\
\text { mereka melalui } \\
\text { komunikasi } \\
\text { (Smith } \\
\text { Dkk,2009) }\end{array}$ & $\begin{array}{l}\text { 1. status dan } \\
\text { kedudukan kota } \\
\text { dimata } \\
\text { internasional } \\
\text { 2. kontribusi } \\
\text { penting kota } \\
\text { ditingkat dunia }\end{array}$ & Likert \\
\hline $\begin{array}{l}\text { Potential } \\
\text { X2 }\end{array}$ & $\begin{array}{l}\text { Potensi adalah } \\
\text { kemampuan } \\
\text { atau kekuatan } \\
\text { atau daya, } \\
\text { dimana potensi } \\
\text { dapat } \\
\text { merupakan } \\
\text { bawaan atau } \\
\text { bakat dan hasil } \\
\text { stimulus atau } \\
\text { latihan dalam } \\
\text { perkembangan } \\
\text { (Abi Hafiz, } \\
\text { 2013) }\end{array}$ & $\begin{array}{l}\text { 1.kota } \\
\text { memberikan } \\
\text { kesempatan } \\
\text { ekonomi yang } \\
\text { baik } \\
\text { 2. kota } \\
\text { menawarkan } \\
\text { pendidikan } \\
\text { kepada } \\
\text { masyarakat } \\
\text { 3. kota memiliki } \\
\text { kemudahan } \\
\text { akses sebagai } \\
\text { pemilihan } \\
\text { tempat tinggal }\end{array}$ & Likert \\
\hline Place X3 & $\begin{array}{l}\text { Menurut } \\
\text { Kasmir (2011) } \\
\text { yaitu tempat } \\
\text { melayani } \\
\text { konsumen, } \\
\text { dapat juga di } \\
\text { artikan tempat } \\
\text { untuk } \\
\text { memajangkan } \\
\text { barang - barang } \\
\text { dagangannya. }\end{array}$ & $\begin{array}{l}\text { 1. aspek fisik } \\
\text { kota } \\
\text { 2. kenyamanan } \\
\text { kota dalam } \\
\text { melakukan } \\
\text { perjalanan } \\
\text { 3. keindahan } \\
\text { penataan kota } \\
\text { 4. kota memiliki } \\
\text { cuaca yang baik }\end{array}$ & Likert \\
\hline
\end{tabular}

Jurnal Insitusi Politeknik Ganesha Medan 


\begin{tabular}{|c|c|c|c|}
\hline People X5 & $\begin{array}{l}\text { People adalah } \\
\text { sejumlah besar } \\
\text { orang yang } \\
\text { tinggal dalam } \\
\text { wilayah yang } \\
\text { sama, relative } \\
\text { indeopendent } \\
\text { dan orang - } \\
\text { orang diluar } \\
\text { wilayah itu, dan } \\
\text { memiliki } \\
\text { budaya yang } \\
\text { relative sama } \\
\text { (Richard T. } \\
\text { Schaefaer dan } \\
\text { Robert P. } \\
\text { Lamm, 2011) }\end{array}$ & $\begin{array}{l}\text { 1. penduduk } \\
\text { kota bersahabat } \\
\text { 2. penduduk } \\
\text { dapat bertukar } \\
\text { budaya dan } \\
\text { bahasa } \\
\text { 3. kota } \\
\text { menimbulkan } \\
\text { rasa aman }\end{array}$ & Likert \\
\hline Pulse X4 & $\begin{array}{l}\text { Pulse adalah } \\
\text { sebagai sesuatu } \\
\text { yang menarik } \\
\text { dan bernilai } \\
\text { untuk di } \\
\text { kunjungi dan } \\
\text { dilihat (S. } \\
\text { Pendit, 2009) }\end{array}$ & $\begin{array}{l}\text { 1. kota memiliki } \\
\text { nuansa gaya } \\
\text { hidup urban } \\
\text { 2. pengunjung } \\
\text { mudah } \\
\text { menemukan hal } \\
\text { - hal menarik di } \\
\text { kota tersebut }\end{array}$ & Likert \\
\hline $\begin{array}{l}\text { Prerequisite } \\
\text { X6 }\end{array}$ & $\begin{array}{l}\text { Prerequisite } \\
\text { adalah } \\
\text { gambaran dari } \\
\text { layanan yang } \\
\text { disediakan oleh } \\
\text { system, batasan } \\
\text { - batasan dari } \\
\text { system dan bias } \\
\text { juga berupa } \\
\text { definisi } \\
\text { matematis } \\
\text { fungsi system } \\
\text { (zave, 2011) } \\
\end{array}$ & $\begin{array}{l}\text { 1. kualitas dasar } \\
\text { kota } \\
2 . \text { kota } \\
\text { memberikan } \\
\text { kepuasan } \\
\text { dengan } \\
\text { akomodasi yang } \\
\text { disediakan } \\
\text { 3. kota memiliki } \\
\text { kemudahan } \\
\text { akses } \\
\text { pemenuhan } \\
\text { kebutuhan } \\
\end{array}$ & Likert \\
\hline
\end{tabular}

\section{CONCLUSIONS}

1. Hasil uji t (Uji parsial) adalah untuk nilai $\mathrm{t}_{\text {hitung }}$ Presence sebesar 0.179>1,996 ( $\mathrm{n}-4=73-4=69 \alpha 5 \%$ ) kemudian nilai sig $8.59<0,05$ sehingga Ha diterima dan H0 ditolak artinya Presence signifikan mempengaruhi Minat Kunjung.

2. hasil uji $\mathrm{t}$ (Uji parsial) adalah untuk nilai $\mathrm{t}_{\text {hitung }}$ Potential sebesar sebesar $3.663>1,996(n-4=73-4=69 \alpha 5 \%)$ kemudian nilai sig $0.00<0,05$ sehingga $\mathrm{Ha}$ diterima dan $\mathrm{H} 0$ ditolak artinya Potential tidak signifikan mempengaruhi Minat Kunjung. 
3. hasil uji $\mathrm{t}$ (Uji parsial) adalah untuk nilai $\mathrm{t}_{\text {hitung }}$ Place sebesar sebesar 2.187>1,996 (n-4 = $73-4=69 \alpha 5 \%)$ kemudian nilai sig $0.32<0,05$ sehingga Ha diterima dan $\mathrm{H0}$ ditolak artinya Place signifikan mempengaruhi Minat Kunjung.

4. hasil uji $\mathrm{t}$ (Uji parsial) adalah untuk nilai $\mathrm{t}_{\text {hitung }}$ People sebesar sebesar $0.037>1,996(n-4=73-4=69 \alpha 5 \%)$ kemudian nilai sig 9.70<0,05 sehingga Ha diterima dan $\mathrm{H} 0$ ditolak artinya People tidak signifikan mempengaruhi Minat Kunjung.

5. hasil uji $\mathrm{t}$ (Uji parsial) adalah untuk nilai thitung Pulse sebesar sebesar 2.644>1,996 (n-4 = $73-4=69 \alpha 5 \%)$ kemudian nilai sig $0.10<0,05$ sehingga $\mathrm{Ha}$ diterima dan $\mathrm{H0}$ ditolak artinya Pulse signifikan mempengaruhi Minat Kunjung.

6. hasil uji t (Uji parsial) adalah untuk nilai $t_{\text {hitung }}$ Prerequisite sebesar sebesar $0.155>1,996(n-4=73-4=69 \alpha 5 \%)$ kemudian nilai sig $8.77<0,05$ sehingga $\mathrm{Ha}$ diterima dan $\mathrm{HO}$ ditolak artinya Prerequisite tidak signifikan mempengaruhi Minat Kunjung.

7. nilai $F_{\text {hitung }}$ sebesar 27.918 dengan tingkat signifikan 0,00. Karena $F_{\text {hitung }} 27.918>$ $\mathrm{F}_{\text {tabel }} 2.13$ dan probabilitas signifikan jauh lebih kecil dari 0,05 yaitu $0,00<0,05$, maka model regresi dapat dikatakan bahwa presence, potential, place, people, pulse, prerequisite, secara serempak dan signifikan berpengaruh terhadap Minat Kunjung.

\section{REFERENCES}

Abdurrahman Hikmah Ramadhan., Suharyono., \& Srikandi Kumadji. (2015). Pengaruh City Branding Terhadap Minat Berkunjung Serta Dampaknya Pada Keputusan Berkunjung (Survey Pada Wisatawan Kota Surabaya). Jurnal Administrasi Bisnis (JAB) Vol.28.

Adhiimsyah Luthfi., \& Aldila Intaniar Widyaningrat. (2013). Konsep City Branding Sebuah Pendekatan "The City Brand Hexagon" Pada Pembentukan Identitas Kota. Seminar Nasional Manajemen Dan Bisnis Ke-3.

Alpiannoor. M. A., Mawardi, Kholid, \& Sanawiri, Brillyanes. (2015). Pengaruh City Branding Serta Tagline "Kediri Lagi" Terhadap Minat Kunjung Wisatawan Domestic Kabupaten Kediri. Jurnal Management.

Amellia Fatimatus Saputri., \& Achmad Fauzi. (2018). Pengaruh City Branding Terhadap City Image Dan Keputusan Berkunjung Ke Kota Wisata Batu (Servei Pada Wisatawan Yang Berkunjung Ke Kota Wisata Batu). Jurnal Administrasi Bisnis (JAB), 54(1).

Anholt, S.. (2012). Competitive Identity : The New Management For Notion, Cities And Regian. USA : Palgrave Macmillan. 
Bayu Hendrawan Suroso., \& Sri Setyo Iriani. (2014). Pengaruh Inovasi Produk Dan Harga Terhadap Minat Beli Mie Sedaap Cup. Julnal Ilmu Manajemen.

Chaerani, R. Y. (2014). Pengaruh City Branding Terhadap City Image (Studi Pencitraan Kota Solo : "The Spirit Of Java"). (Doctoral Dissertation, Universitas Sultan Agung Ageng Tirtayasa).

Elbert dan Griffin. (2009). Pengantar Bisnis. Edisi kesepuluh. Jakarta: Erlangga.

Ferdiand, Agusty. (2014). Metode Penelitian Manajemen . Semarang : Penerbit Universitas Diponegoro.

Imam Ghozali (2013). Aplikasi Analisis Multivariate Dengan Program SPSS. Semarang : BP Universitas Diponegoro Edisi 7

Indriani. Jesi, \& Chandra Kuswoyo. (2017). Pengaruh City Branding Terhadap City Image Dan Keputusan Berkunjung Wisatawan Ke Kabupaten Purwakarta. Jurnal Manajemen Maranatha.

Ismayanti. (2010). Pengantar Parawisata. Jakarta : PT.Gramedia.

Kotler, Philip and Garry Armstrong. (2011). Prinsip - Prinsip Pemasaran. Jakarta: Erlangga

Kotler, Philip dan Kevin Lane Keller. (2009). Manajemen Pemasaran. Edisi

Ketiga belas Jilid I dan II. Cetakan Ke empat. Jakarta: Erlangga

Kotler, Philip, John T. Brown, And James C. Makens. (2011). Markrting For Hospitality And Tourism. Fourth Edition. New Jersey : Pearson Education.

Kuncoro, M. (2014). Metode Riset Untuk Bisnis dan Ekonomi. Jakarta : Erlangga.

Norfiyanti, Kiki. (2012). Analisis Pengaruh Citra Merek, Persepsi Harga, Dan Daya Tarik Iklan Terhadap Minat Beli Konsumen Pada Produk Air Minum Dalam Kemasan (AMDK) Galon Merek AQUA (Studi Kasus Pada Mahasiswa Di Kota Semarang.(Doctoral Dissertation, Universitas Diponegoro Semarang).

Nurhadidah, Mahda (2016). Analisis Pengaruh City Branding Dan Word Of Mouth Terhadap Minat Berkunjung Serta Dampaknya Terhadap Keputusan Berkunjung Wisatawan Ke Kota Bandung. (Studi Kasus Pada Mahasiswa Di Kota Tangerang Selatan Yang Pernah Berkunjung Ke Kota Bandung). (Doctoral Dissertation, Fakultas Ekonomi Dan Bisnis UIN Starif Hidayatullah Jakarta). 
Nurivani, S. Z. (2015). Pengaruh City Branding "Enjoy Jakarta" Terhadap Citra Kota Dan Keputusan Berkunjung Youth Traveler Ke Jakarta. (Doctoral Dissertation, Fakultas Ekonomi Dan Bisnis Uin Syarif Hidayatullah Jakarta).

Sugiyono. (2010). Metode Penelitian Bisnis : Bandung : CV. Alfabeta.

Tjiptono, Fandi. (2011). Brand Manajement \& Strategy. Malang : Bayu Media Publishing.. 